\title{
A REVIEW OF MATHEMATICAL MODELS FOR PERFORMANCE PREDICTION OF FLEXIBLE PAVING ON EXPANSIVE SOILS
}

\author{
Marianna Luna Sousa Rivettia, Felipe Costa Albuquerquea; Luiza Santos Giron \\ Margalho ${ }^{a}$, Paulo César Burgos ${ }^{a}$, Larissa da Silva Paes Cardoso ${ }^{a}$, Leonardo Machado \\ Borges $^{b}$ \\ a SENAI CIMATEC, Brazil, \\ b VIABAHIA, Brazil
}

\begin{abstract}
:
The presence of expansive soils in road works is linked to deformations, which causes an increase in the need for maintenance. There is monitoring software, however, they do not take into account parameters of the behavior of expansive soils. In this sense, a mathematical model with inputs of expansive soil parameters, are essential to reduce production and maintenance costs. This study aims to seek, through a systematic literature review, scientific publications, and patents that include mathematical models capable of evaluating the performance of pavements through the behavior of expansive soils. It was observed that there are few publications related to the theme and the models found do not take into account specific parameters of the behavior of expansive soils.
\end{abstract}

Keywords: Expansive Soil; Pavement; Performance prediction model; Pavement performance monitoring; Mathematic model for pavement performance prediction.

\section{UMA REVISÃO DE MODELOS MATEMÁTICOS PARA PREVISÃO DE DESEMPENHO DE PAVIMENTOS FLEXÍVEIS SOBRE SOLOS EXPANSIVOS}

Resumo: A presença de solos expansivos em obras rodoviárias está ligada às deformações, o que provoca um aumento na necessidade de manutenção. Existem softwares de monitoramento, porém, não levam em consideração parâmetros dos solos expansivos. Neste sentido, um modelo matemático tendo como inputs esses parâmetros, são essenciais para a redução de custos. Este estudo visa buscar, através de uma revisão de literatura sistemática, publicações científicas e patentes que contemplem modelos matemáticos capazes de avaliar o desempenho dos pavimentos através do comportamento de solos expansivos. Observou-se que existem poucas publicações relacionadas ao tema e os modelos encontrados não consideram os parâmetros específicos do comportamento dos solos expansivos.

Palavras-chave: Solo expansivo; Pavimento; Desempenho de modelo de previsão; Monitoramento de desempenho do pavimento; Modelo matemático para previsão de desempenho de pavimentos. 


\section{INTRODUCTION}

Expansive soil, also called massapé soil, is a clay soil, with high swelling potential and contraction, with montmorillonite as the predominant clay [1]. Because the massapé soil has a high content of fines, it has high expandability and high capacity water adsorption, as it has a large specific surface [2]. According to Simões [3], capacity the expansion of the soil depends on the type of clay, the cation exchange potential, and the suction of the soil. However, there are external factors that cause the expansion of the soil, such as its increase in humidity, due to rain, variation in the water table level, and reduction of total soil stresses, such as excavations or cuts in slopes [3].

In road works, due to the expansion of the soil, the pavement rises, causing damage to it. In this way, expansive soils are responsible for the appearance of problems in the pavement structures [4]. According to Cuervo et al. [5], the presence of expansive soils in road works is directly related to deformations that generate damage to the runway, requiring greater investments in maintenance. According to Chen et al. [6], billions of dollars are spent annually to restructure the asphalt pavement and keep it regular due to problems caused by the high volumetric variation of expansive soils. Research has been carried out proposing several solutions that seek to remedy the expansion of the soil and the increase in humidity, in which they provide guidelines for rehabilitating the pavements [6].

However, it is important to monitor the pavement to control its performance. Some indexes are established to analyze the performance of the pavement, quantifying the deviations from the pavement surface about the project, such as the IRI - International Roughness Index used to measure the irregularity [7]. According to Borges [7], the IRI is one of the indicators that have the greatest influence on operating costs for road users, being an essential parameter for assessment at the project level and for the management of the network and its use in forecasting the performance of the pavement.

According to the DNIT Restoration Manual [8], it is possible to check the quality level of the road according to the IRI and other parameters such as Global Severity Index, ICPF (Flexible Pavement Condition Index), and TR (Cracking). Aiming at decision-making and preventive planning of costs and works, highway concessionaires use software to monitor the conditions of the soil and asphalt pavement that use these indexes. However, these programs do not take into account specific parameters of the behavior of expansive soils, which impacts on the proper management of structures arranged in regions with the presence of expansive soil.

Cuervo et al. [5] developed a study that presents a comparison between performance parameters of pavements that have or not the massapé soil in its structure, its influence on the maintenance of a highway, and its importance in the performance evaluations of a Concession. In this study, the authors verified a lower performance of the pavement in sections with massapé soil, requiring a differentiated investment in road maintenance in the search to meet the minimum performance parameters established for the Concessions. The study showed the weakness in the performance analysis methodology imposed on the Concessionaires.

In this context, the construction of a mathematical model with inputs of expansive soil parameters, obtained through traditional tests and unconventional tests, 
is essential for increasing the productivity of infrastructure systems, reducing production and maintenance costs, and the time spent on non-productive activities.

Therefore, this article aims to search for scientific works and patents that make use of mathematical/numerical models to predict the behavior of pavements supported on expansive soils, seeking to determine the influence of these soils on their performance and, consequently, on the maintenance of highways.

\section{METHODOLOGY}

This study was developed through a search for patents and technical publications, such as articles, theses, dissertations, course completion work, and books that include mathematical/numerical models for predicting pavement performance and for predicting soil behavior. The research was carried out through a priority search, being developed with the support of the Intellectual Property Center of SENAI CIMATEC.

The anteriority search was made in the period from 03 to 14 February 2020, through the Derwent Innovation platform and to achieve the proposed objective, initially, it was sought to identify the databases to be consulted; after identifying the bases, the Boolean descriptors and connectors were defined; following up, the inclusion and exclusion criteria of the works were defined; and, finally, analysis and evaluation of all studies included in the review was carried out, producing a synthesis of the information and results found.

Both simple and advanced searches were performed in the researched databases, including CIP-International Patent Classification. The keywords were defined in the title (full expression) and summary of patent documents, articles, theses, dissertations, course completion works and books, combined through the use of Boolean connectors, according to the manual of each base and was also a search by the number of International Patent Classification.

The inclusion criteria for publications were: articles, books, theses, and dissertations, which addressed the use of mathematical models in predicting the behavior of pavements and soils, published between 1990 and 2020, in English or Portuguese, and articles available in the whole. All works published outside the period and in languages other than those defined were excluded, and articles with availability only upon payment.

The keywords used in the research were:

- $\quad$ Expansive Soil;

- Pavement;

- $\quad$ Performance prediction model;

- $\quad$ Pavement performance monitoring;

- Mathematic model for pavement performance prediction.

The databases available for the search were:

- INPI - National Institute of Industrial Property;

- $\quad$ ESPACENET - European Patent Office;

- $\quad$ USPTO - United States Patent and Trademark Office; 
- $\quad$ SCIELO - Scientific Electronic Library on line;

- $\quad$ Portal of Journals of CAPES;

- $\quad$ WIPO - World Intellectual Property Organization;

- Google patents;

- Derwent Innovation.

\section{RESULTS AND DISCUSSION}

In the patent database, 4 patents were found related to massapé soil and behavior simulation in reduced models, however, no patent was found for mathematical models that simulate the behavior of expansive soil and pavement performance. It was observed in the patent search that the main country of origin of the patents in China.

Among the researched works, it is worth highlighting the following articles: Design model for roughness and serviceability of pavements on expansive soils, Modeling swelling-shrinkage behavior of compacted expansive soils during wettingdrying cycles and Numerical Simulation of Moisture Fluctuations in Unsaturated Expansive Clay, Heave / Settlement Predictions, and Validation with Field Measurements. These articles highlight and demonstrate the mathematical modeling of the expansion and retraction behavior of expansive soils, as well as the simulation of these behaviors and correlation of the results obtained with field data.

According to Hong et al. [9] the model was developed to predict pavement roughness caused by both expansive soils and traffic in terms of the serviceability index (SI) and the International Roughness Index (IRI). Nowamooz et al. [10] developed one model for unsaturated expansive soils subjected to wetting and drying cycles. The models take into account the expansion potential and suction envelope within the subgrade soil [12]. Khan et al. [26] proposes a model using the Winkler foundation theory to analyze the pavement by considering it as a beam resting on expansive soil.

Application of the developed models will facilitate noninvasive estimations of the response of soil strength and stiffness properties to variations in moisture [23].

The main works found in the literature related to the subject are shown in Table 1.

Table 1. Result of the systematic review.

\begin{tabular}{|c|c|}
\hline $\begin{array}{c}\text { Title } \\
\text { Design model for roughness and serviceability of pavements on } \\
\text { expansive soils }\end{array}$ & Author(s) \\
\hline $\begin{array}{c}\text { Shakedown modeling of unsaturated expansive soils subjected to } \\
\text { wetting and drying cycles }\end{array}$ & {$[10]$} \\
\hline $\begin{array}{c}\text { Numerical modeling for remedial measures of shallow slope failure } \\
\text { using recycled plastic pins }\end{array}$ & {$[11]$} \\
\hline $\begin{array}{c}\text { Arizona and Texas pavement design on expansive subgrade soil: a } \\
\text { comparison }\end{array}$ & {$[12]$} \\
\hline $\begin{array}{c}\text { Applicability of the International Roughness Index as a Predictor of } \\
\text { Asphalt Pavement Condition }\end{array}$ & {$[13]$} \\
\hline
\end{tabular}




\begin{tabular}{|c|c|}
\hline $\begin{array}{l}\text { Evaluation of the longitudinal irregularity of the pavements with data } \\
\text { collected by smatphones }\end{array}$ & [14] \\
\hline $\begin{array}{l}\text { Evaluation of low-cost consumer-level mobile phone technology for } \\
\text { measuring international roughness index (IRI) values }\end{array}$ & [15] \\
\hline $\begin{array}{l}\text { International Roughness Index: Relationship to Other } \\
\text { Measures of Roughness and Riding Quality }\end{array}$ & [16] \\
\hline $\begin{array}{l}\text { IRI Estimation Using Probabilistic Analysis } \\
\text { of Acoustic Measurements }\end{array}$ & [17] \\
\hline $\begin{array}{c}\text { Modeling swelling-shinkage behavior of compacted expansive soils } \\
\text { during wetting-drying cycles }\end{array}$ & [18] \\
\hline $\begin{array}{c}\text { Relationships Between International Roughness Index and Present } \\
\text { Serviceability Rating }\end{array}$ & [19] \\
\hline $\begin{array}{c}\text { Roughness Progression Model for Asphalt Pavements Using Long- } \\
\text { Term Pavement Performance Data }\end{array}$ & [20] \\
\hline $\begin{array}{l}\text { Possible method of determining structural number for flexible } \\
\text { pavements with the falling weight deflectometer }\end{array}$ & [21] \\
\hline $\begin{array}{l}\text { Proposal for using deflectometric surveys to obtain the corrected } \\
\text { structural number of the pavement }\end{array}$ & [22] \\
\hline $\begin{array}{c}\text { Data-Based Real-Time Moisture Modeling in Unsaturated Expansive } \\
\text { Subgrade in Texas }\end{array}$ & [23] \\
\hline $\begin{array}{c}\text { Data Based Real Time Moisture Modeling in Unsaturated Expansive } \\
\text { Subgrade }\end{array}$ & [24] \\
\hline $\begin{array}{l}\text { Moisture Content-Based Longitudinal Cracking Prediction and } \\
\text { Evaluation Model for Low-Volume Roads over Expansive Soils }\end{array}$ & [25] \\
\hline $\begin{array}{c}\text { Development of Analytic Method for Computing Expansive Soil- } \\
\text { Induced Stresses in Highway Pavement }\end{array}$ & [26] \\
\hline $\begin{array}{c}\text { Numerical Simulation of Moisture Fluctuations in Unsaturated } \\
\text { Expansive Clay, Heave/Settlement Predictions, and Validation with } \\
\text { Field Measurements }\end{array}$ & [27] \\
\hline $\begin{array}{c}\text { Numerical Analysis of Vertical Moisture Barriers in Controlling } \\
\text { Expansive Soils in Presence of Soil Cracks }\end{array}$ & [28] \\
\hline
\end{tabular}

Figure 1. The number of articles over the years.

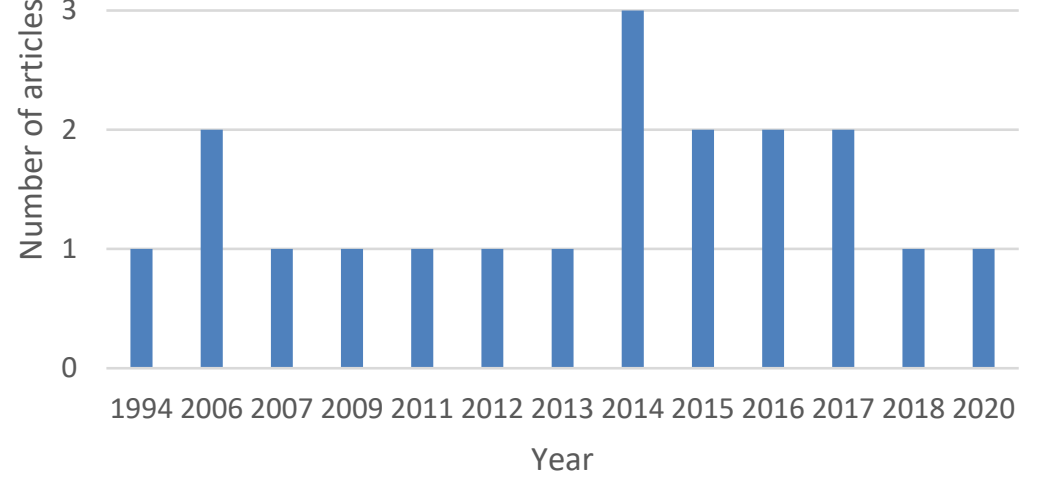


According to Figure 1, it is observed how the publications related to the theme found in the database, started in 1994, in which there is only one publication registered. After more than ten years, in 2006, two publications are registered, with few publications until 2014, in which there are three publications. Between 2014 and 2017, there is an increase in the number of publications, decreasing afterward. It is worth mentioning that articles highlighted about the theme were published in 2006 and 2016.

It is observed with the results found that there are models that seek to simulate the behavior of the massapé soil and others that analyze the performance of the pavement. However, within the scope of the research, no models were found that relate specific parameters of the behavior of expansive soils, such as Attemberg Limits, Cation Exchange Capacity (CTC), Free Expansion Pressure, Expansion Pressure, Corrected Skempton Activity, percentage clay fraction, among others, with the pavement performance. According to the systematic review, there are few published works related to the theme, with a reduction in the number of works in the last three years.

\section{CONCLUSION}

In this work, a survey of the state of the art on mathematical models for predicting expansive soil behavior in pavement performance was presented. It was observed that the first publication related to the theme occurred in 1994 and only after ten years did new publications come, with an average of one publication per year until 2014, with an increase until 2017, and subsequently, a reduction in publications.

It was found that the models tried to analyze the behavior of expansive soil and others that analyze the performance of the pavement but do not consider specific parameters of the behavior of expansive soils in the performance of the highways, which impacts on the proper management of the structures arranged in regions with expansive soil. It is important the development of a mathematical model capable of predicting the influence of the massapé soil behavior on the pavement performance for the proper management of the structures arranged in expansive soil regions.

\section{Acknowledgments}

The authors are grateful for the financial support of partner institutions SENAI CIMATEC and VIABAHIA through the program of resources EMBRAPII.

\section{REFERENCES}

1 SIMÕES, P. R. M. Mecanismos de instabilização dos taludes naturais das formações expansivas da Bacia sedimentar do Recôncavo Baiano. Monografia para o título de doutor em ciências em Engenharia Civil. Universidade Federal do Rio de Janeiro, Rio de Janeiro-RJ, 1991. 
2 SOBRAL, Hernani Sávio. Contribuição ao estudo dos massapês como solos para construção. Salvador: UFBA. Tese (Doutorado) - Escola de Belas Artes, Universidade Federal da Bahia, Salvador, 1956.

${ }^{3}$ SIMÕES de Oliveira, A.G.; JESUS, A.C; MIRANDA, S.B. Estudo Geológico Geotécnico dos Solos Expansivos da Região do Recôncavo Baiano. II Simpósio Brasileiro de Jovens Geotécnicos - II Geojovem. Nova Friburgo/RJ, 2006.

${ }^{4}$ DNIT. Manual de Pavimentação. Instituto de Pesquisas Rodoviárias (IPR), Rio de Janeiro-RJ, 2006.

${ }^{5}$ CUERVO, Juan Cabral; et.al. Massapê, Item de Desequilíbrio na Manutenção Rodoviária: O Caso da Rodovia BR-324/BA. Revista Científica Multidisciplinar Núcleo do Conhecimento. Ano 2, Vol. 15. pp 149-162, 2017.

${ }^{6} \mathrm{HAO}$, Chen Dar; et al. Journal of Performance of Constructed Facilities. Vol. 26 Issue 3, p335-344. 10p. 7, 2012.

${ }^{7}$ BORGES, Leonardo Machado. Massapê: Impactos nas condições funcionais e estruturais do pavimento da BR-324, trecho entre Salvador e Feira de Santana, 2017.

8 DNIT, Manual de Restauração de Pavimentos. Instituto de Pesquisas Rodoviárias (IPR), Rio de Janeiro-RJ, 2006.

${ }^{9}$ HONG, G.T.; BULUT, R.; AUBENY, C.P.; JAYATILAKA, R.; LYTTON, R.L. Design model for roughness and serviceability of pavements on expansive soils. Geology and properties of earth materials, 2006.

${ }^{10}$ NOWAMOOZ, H.; LI, K.; CHAZALLON, C. Shakedown modeling of unsaturated expansive soils subjected to wetting and drying cycles. 3RD EUROPEAN CONFERENCE ON UNSATURATED SOILS - E-UNSAT, 2016.

${ }^{11}$ HOSSAIN, J.; HOSSAIN, M.S.; LOZANO, N.; KHAN, S. Numerical modeling for remedial measures of shallow slope failure using recycled plastic pins. Geotechnical engineering for disaster mitigation and rehabilitation 2011/geotechnical and highway engineering - practical applications, challenges and opportunities $\mid: 650$ 655, 2011.

${ }^{12}$ BRIAN, J. A. Arizona and Texas pavement design on expansive subgrade soil: a comparison. Arizona State University, August, 2009.

${ }^{13}$ KYUNGWON P; NATACHA, E. THOMAS, K.; WAYNE, L. Applicability of the International Roughness Index as a Predictor of Asphalt Pavement Condition. Journal of Transportation Engeneering. Volume 133, issue 12 - december, 2007.

${ }^{14} \mathrm{BISCONSINI,} \mathrm{D.} \mathrm{R.} \mathrm{Avaliação} \mathrm{da} \mathrm{irregularidade} \mathrm{longitudinal} \mathrm{dos} \mathrm{pavimentos}$ com dados coletados por smartphones. Universidade de São Paulo - Escola de Engenharia de São Carlos - Departamento de Engenharia de Transportes, 2016.

${ }^{15}$ HANSON, T.; CAMERON,C.; HILDEBRAND, E. Evaluation of low-cost consumer-level mobile phone technology for measuring international roughness index (IRI) values. Nrc Research Press, 2014.

${ }^{16}$ PATERSON, W. D. O. International Roughness Index: Relationship to Other

Measures of Roughness and Riding Quality. Tranportation Research Record,1084. 
17 ZHAO, Y.; MCDANIEL, J. G.; WANG, M.L. IRI Estimation Using Probabilistic Analysis of Acoustic Measurements. Materials Performance and Characterization. vol. 2, no. 1, 2013.

18 GANG, W.; XING, W. Modeling swelling-shinkage behavior of compacted expansive soils during wetting-drying cycles. NRC Research Press, 2014.

19 BASHAR, AL-OMARI MICHAEL, I. D. Relationships Between International Roughness Index and Present Serviceability Rating. Tranportation Research Record. 1435, 1994.

20 JAY, N.; MEEGODA.S. G. Roughness Progression Model for Asphalt Pavements Using Long-Term Pavement Performance Data. Journal Of Transportation Engeneering, 2014.

${ }^{21}$ SCHNOOR, H.; HORAK, E. Possible method of determining structural number for flexible pavements with the falling weight deflectometer. 31st Southern African Transport Conference (SATC 2012), 2012.

22 RAMOS, D.; SESTINI, V. M.; REIS, A. M.; PRIETO, V.; SUZUKI, C. Y.; PREUSSLER, E. S.; VALE, A. F.; PEREIRA, A. C. O.; SANTOS, C. R. G. Proposta para utilização de levantamentos deflectométricos na obtenção do número estrutural corrigido do pavimento (SNC). V Jornadas Luso-Brasileiras De Pavimentos: Políticas e Tecnologias, 2016.

${ }^{23}$ AHMED, A.; HOSSAIN, S.; KHAN, M. S.; SHISHANI, A. Data-Based Real-Time Moisture Modeling in Unsaturated Expansive Subgrade in Texas. Journal Of The Transportation Research Record, 2018.

${ }^{24}$ AHMED,A.;HOSSAIN,S.; KHAN, M. S.; SHISHANI, A. Data Based Real Time Moisture Modeling in Unsaturated Expansive Subgrade. PanAm Unsaturated Soils, 2017.

${ }^{25}$ WANYAN, Y.; ABDALLAH, I.;NAZARIAN, S.; PUPPALA, A. J. Moisture ContentBased Longitudinal Cracking Prediction and Evaluation Model for Low-Volume Roads over Expansive Soils. Journal Of Materials In Civil Egineering. Volume 27, Issue 10 - October, 2015.

26 KHAN, A.; WANG, J. X.; SARKER, D. Development of Analytic Method for Computing Expansive Soil-Induced Stresses in Highway Pavement. International Journal Of Geomechanics. Volume 20 issue 2, February 2020.

27 IKRA, B. A.; WANG, J. X. Numerical Simulation of Moisture Fluctuations in Unsaturated Expansive Clay, Heave/Settlement Predictions, and Validation with Field Measurements. PanAm unsaturated soils, 2017.

${ }^{28}$ CHEN, L.; BULUT, R. Numerical Analysis of Vertical Moisture Barriers in Controlling Expansive Soils in Presence of Soil Cracks. IFCEE, 2015. 